\title{
CALCULATION OF EIGENVALUES OF COUETTE SPECTRAL PROBLEM BY METHOD OF REGULARIZED TRACES
}

\author{
S.I. Kadchenko ${ }^{1}$, kadchenko@masu.ru, \\ L.S. Ryazanova ${ }^{1}$, ryazanova2006@rambler.ru, \\ A.I. Kadchenko ${ }^{1}$, akadchenko@mail.ru. \\ ${ }^{1}$ Nosov Magnitogorsk State Technical University, Magnitogorsk, Russian Federation.
}

\begin{abstract}
One can find the eigenvalues of non-selfadjoint operators only by numerical methods. The use of these methods is associated with large computational difficulties. Therefore, the development of a new method for calculating of eigenvalues of non-self-adjoint operators has great theoretical and practical interest. Non iterative method for finding of eigenvalues of perturbed self-adjoint operators is developed on the basis of the theory of regularized traces. This method is called the method of regularized traces. The linear formulas for computing of the eigenvalues of the discrete operators, which are semi-bounded from below, were found. Using them, one can compute the eigenvalues of perturbed self-adjoint operator with any their number. Note that for this computation it does not matter whether the eigenvalues with less number are known or not. Numerical calculations of eigenvalues for the spectral problems, which are generated by the equations of mathematical physics, show that for large numbers of eigenvalues the proposed formulas give more exact result than the Galerkin method. In addition, the obtained formulas allow to compute the eigenvalues of perturbed self-adjoint operator with very large number, such that the use of the Galerkin method becomes difficult. The algorithm of application of the method of regularized traces for finding of eigenvalues of the Couette spectral problem of hydrodynamic stability theory is constructed. This problem studies the stability of the flow of a tough liquid between two rotating axisymmetric cylinders to small perturbations of the basic flow. A feature of this problem is the fact that the differential operator is a matrix one. Numerical experiments have shown the high computational efficiency of the proposed algorithm of computing of the eigenvalues of the studied spectral problem.

The algorithm of application of the method of regularized traces for spectral problems, which are generated by the matrix discrete operators limited from below, is constructed in the paper.

Keywords: eigenvalues and eigenfunctions of operators; corrections of the perturbation theory; discrete operators; self-adjoint operators; the theory of hydrodynamic stability.
\end{abstract}

\section{Introduction}

This article is a continuation of works [1-15], which are associated with the development of non iterative numerical method for computing of eigenvalues of perturbed self-adjoint operators by the method of regularized traces (RT). The basic ideas of the method of regularized traces are the following. To solve the problem of finding of the eigenvalues of operator $T+P$

$$
(T+P) u=\mu u
$$

where $T$ - a discrete semi-bounded from below operator, $P$ - limited operator defined in a separable Hilbert space $H$. Suppose that the eigenvalues $\left\{\beta_{n}\right\}_{n=1}^{\infty}$ of the operator $T$ are known and are numbered in non-decreasing order of their values with regard to algebraic 
multiplicity, and orthonormal eigenfunctions $\left\{v_{n}\right\}_{n=1}^{\infty}$, corresponding to these eigenvalues. Denote the multiplicity of the eigenvalue $\beta_{n}$ by $\nu_{n}$, and the number of all unequal to each other eigenvalues $\beta_{n}$, which lie inside the circle $T_{n_{0}}$ of radius $\rho_{n_{0}}=\frac{\left|\beta_{n_{0}+1}+\beta_{n_{0}}\right|}{2}$ with center in the beginning of coordinate complex plane by $n_{0}$. Let $\left\{\mu_{n}\right\}_{n=1}^{\infty}$ be eigenvalues of the operator $T+P$, which are numbered in non-decreasing order of their real parts. If inequalities $q_{n}=\frac{2\|P\|}{\left|\beta_{n+\nu_{n}}-\beta_{n}\right|}<1$ are true for all $n \geq n_{0}$, then the first $m_{0}=\sum_{n=1}^{n_{0}} \nu_{n}$ of the eigenvalues of $\left\{\mu_{n}\right\}_{n=1}^{m_{0}}$ of the operator $T+P$ are solutions of the system of $m_{0}$ nonlinear equations of the form

$$
\sum_{k=1}^{m_{0}} \mu_{k}^{p}=\sum_{k=1}^{m_{0}} \beta_{k}^{p}+\sum_{k=1}^{\infty} \alpha_{k}^{(p)}\left(m_{0}\right), p=\overline{1, m_{0}} .
$$

Here $\alpha_{k}^{(p)}\left(m_{0}\right)=\frac{(-1)^{k} p}{2 \pi k i} S p \int_{T_{n_{0}}} \beta^{p-1}\left[P R_{\beta}(T)\right]^{k} d \beta$ are $k$-tide corrections to the perturbation theory of the operator $T+P$ of integer order $p, R_{\beta}(T)$ is the resolvent of the operator $T$.

Numerical reiterating method of regularized traces (MS) is based on the system of equations (2). This method allows to find the eigenvalues of perturbed self-adjoint operators in the case when the self-adjoint operators have eigenvalues of an arbitrary multiplicity.

If eigenfunctions $\left\{v_{n}\right\}_{n=1}^{\infty}$ of the operator $T$ are basis in $H$, then eigenvalues $\left\{\mu_{n}\right\}_{n=1}^{m_{0}}$ of the operator $T+P$ are calculated by the formulas [15]:

$$
\mu_{n}=\beta_{n}+\left(P v_{n}, v_{n}\right)+\delta(n), n=\overline{1, m_{0}},
$$

where $\delta(n)$ satisfy to the estimates $|\delta(n)| \leq(2 n-1) \rho_{n} \frac{q^{2}}{1-q}$.

An algorithm of use of the PC method for finding of the eigenvalues of the spectral Couette problem of the hydrodynamic theory of stability is developed in the paper.

\section{Spectral Couette Problem}

Consider the problem of hydrodynamic stability of the axisymmetric flow of a viscous incompressible fluid between two rotating concentric cylinders. Let us to introduce a cylindrical coordinate system with axis $O Z$ along axis of cylinders. In the case of rotational symmetry, equation of the first approximation for small perturbations relative with regard to the amplitudes of the stream function $\widehat{\psi}(r)$ and transversal velocity component $\widehat{v}(r)$ are of the form [16]

$$
\left\{\begin{array}{l}
\frac{1}{r} T^{2} \widehat{\psi}+2 \lambda R v \widehat{v}=\mu T \widehat{\psi}, \\
\frac{1}{r} T \widehat{v}-2 \lambda R A \widehat{\psi}=\mu \widehat{v} .
\end{array} \quad r_{1}<r<r_{2},\right.
$$

Here $A=\frac{\frac{\Omega_{2}}{\Omega_{1}}\left(\frac{R_{2}}{R_{1}}\right)^{2}-1}{\left(\frac{R_{2}}{R_{1}}\right)^{2}-1}, B=-\frac{\left(\frac{\Omega_{2}}{\Omega_{1}}-1\right)\left(\frac{R_{2}}{R_{1}}\right)^{2}}{\left(\frac{R_{2}}{R_{1}}\right)^{2}-1}, R_{1}$ and $R_{2}-$ radiuses of inner and outer cylinders, $\Omega_{1}$ and $\Omega_{2}$ are their angular velocities of rotation, $R$ - the dimensionless 
Reynolds number, $\lambda$ - wave number, $\mu=R \sigma, \sigma$ - spectral parameter of the Couette problem, $T \widehat{v}=-r \frac{d^{2} \widehat{v}}{d r^{2}}-\frac{d \widehat{v}}{d r}+\left(\frac{1}{r}+\lambda^{2} r\right) \widehat{v}, v=A r+\frac{B}{r}, r_{1}=1, r_{2}=R_{2} / R_{1}$. The boundary conditions for the differential equations system (4) are following:

$$
\left.\widehat{v}\right|_{r=r_{1}, r_{2}}=\left.\widehat{\psi}\right|_{r=r_{1}, r_{2}}=\left.\frac{d \widehat{\psi}}{d r}\right|_{r=r_{1}, r_{2}}=0
$$

If the real part of $\sigma_{r}$ of complex numbers $\sigma=\sigma_{r}+\sigma_{i} i$ is positive, then due to linear theory, the perturbation is unstable. If $\sigma_{r}<0$, then perturbation decays [16].

In separable Hilbert space $L_{2}^{r}\left[r_{1}, r_{2}\right]$ with weight $r$ we introduce the matrix operator

$$
\mathbf{G}=\left(\begin{array}{ll}
\frac{1}{r} T^{2}-\mu T & 2 \lambda R v \\
-2 \lambda R A & \frac{1}{r} T-\mu
\end{array}\right) .
$$

The domain of definition of $\mathbf{D}_{\mathbf{G}}$ of the matrix operator $\mathbf{G}$ consists of all of the matrixcolumns $\boldsymbol{\Phi}$ of the form $\left(\begin{array}{c}\widehat{\psi} \\ \widehat{v}\end{array}\right)$, the elements of which are functions of the class

$$
\begin{aligned}
& \widehat{\psi}(r) \in C^{4}\left(r_{1}, r_{2}\right) \bigcap C^{1}\left[r_{1}, r_{2}\right], \frac{1}{r} T^{2} \widehat{\psi} \in L_{2}^{r}\left[r_{1}, r_{2}\right], \\
& \widehat{v}(r) \in C^{2}\left(r_{1}, r_{2}\right) \bigcap C^{1}\left[r_{1}, r_{2}\right], \frac{1}{r} T \widehat{v} \in L_{2}^{r}\left[r_{1}, r_{2}\right],
\end{aligned}
$$

satisfying the boundary conditions (5), i.e.

$$
\mathbf{D}_{\mathbf{G}}=\left(\begin{array}{c}
\left\{\widehat{\psi} \mid \widehat{\psi} \in C^{4}\left(r_{1}, r_{2}\right) \cap C^{1}\left[r_{1}, r_{2}\right], \frac{1}{r} T^{2} \widehat{\psi} \in L_{2}^{r}\left[r_{1}, r_{2}\right],\right. \\
\left.\left.\widehat{\psi}(r)\right|_{r=r_{1}, r_{2}}=\left.\frac{d \widehat{\psi}(r)}{d r}\right|_{r=r_{1}, r_{2}}=0\right\} \\
\left\{\widehat{v} \mid \widehat{v} \in C^{2}\left(r_{1}, r_{2}\right) \bigcap C^{1}\left[r_{1}, r_{2}\right], \frac{1}{r} T \widehat{v} \in L_{2}^{r}\left[r_{1}, r_{2}\right],\right. \\
\left.\left.\widehat{v}(r)\right|_{r=r_{1}, r_{2}}=0\right\}
\end{array}\right) .
$$

Then the system of equations (4) can be written in the form

$$
\mathbf{G U}=\mathbf{0}, \quad \mathbf{U} \in \mathbf{D}_{\mathbf{G}} .
$$

One can not to apply the method of regularized traces directly to find the eigenvalues of the spectral problem (6). It is so because a matrix differential operator $\mathbf{G}$ cannot be represented as a sum of matrices of self-adjoint and bounded operators. To overcome this difficulty, we build an auxiliary spectral problem, such that the set of its eigenvalues coincides with the set of eigenvalues of the Couette problem (6).

To this end we consider the differential operator $T_{1}$. Suppose that

$$
T_{1} f=-r \frac{d^{2} f}{d r^{2}}-\frac{d f}{d r}+\left(\frac{1}{r}+\lambda^{2} r\right) f
$$


with domain of definition

$$
D_{T_{1}}=\left\{f \mid f \in C^{4}\left(r_{1}, r_{2}\right) \bigcap C^{1}\left[r_{1}, r_{2}\right], \frac{1}{r} T_{1}^{2} f \in L_{2}^{r}\left[r_{1}, r_{2}\right], f\left(r_{1}\right)=f\left(r_{2}\right)=0\right\},
$$

and inhomogeneous boundary problem

$$
\begin{gathered}
T_{1} f=w(r), \quad r_{1}<r<r_{2}, \\
f\left(r_{1}\right)=0, \quad f\left(r_{2}\right)=0 .
\end{gathered}
$$

Theorem 1. The solution of the boundary problem (7) in the domain $D_{T_{1}}$ is unique and is expressed by the formula

$$
f(r)=\frac{G_{1}\left(\lambda r, \lambda r_{1}\right)}{G_{1}\left(\lambda r_{2}, \lambda r_{1}\right)} \int_{r_{1}}^{r_{2}} \xi, G_{1}\left(\lambda r_{2}, \lambda \xi\right) w(\xi) d \xi-\int_{r_{1}}^{r} \xi, G_{1}(\lambda r, \lambda \xi) w(\xi) d \xi, \quad r_{1} \leq r \leq r_{2},
$$

where $G_{1}(\xi, \eta)=I_{1}(\xi) K_{1}(\eta)-I_{1}(\eta) K_{1}(\xi), I_{1}(r)$ - Bessel function of the first order of imaginary argument, $K_{1}(r)$ - the function of Makdonalda of the first order.

Remark 1. The operator $T_{1}$ has an inverse operator $T_{1}^{-1}$ in $D_{T_{1}}$, since the boundary problem (7) has a unique solution in $D_{T_{1}}$.

$$
T_{1}^{-1} f=\frac{G_{1}\left(\lambda r, \lambda r_{1}\right)}{G_{1}\left(\lambda r_{2}, \lambda r_{1}\right)} \int_{r_{1}}^{r_{2}} \xi, G_{1}\left(\lambda r_{2}, \lambda \xi\right) f(\xi) d \xi-\int_{r_{1}}^{r} \xi, G_{1}(\lambda r, \lambda \xi) f(\xi) d \xi
$$

Lemma 1. The operator $T_{1}^{-1}$ on the set $D_{T_{1}}$ is a "right inverse" of the operator $T$.

Substitute

$$
\mathbf{U}=\left(\begin{array}{cc}
T_{1}^{-1} & 0 \\
0 & 1
\end{array}\right)\left(\begin{array}{c}
\widehat{f} \\
\widehat{v}
\end{array}\right)=\mathbf{Q F}
$$

Then

$$
\begin{aligned}
& \mathbf{G U}=\left(\begin{array}{cc}
\frac{1}{r} T^{2}-\mu T & 2 \lambda R v \\
-2 \lambda R A & \frac{1}{r} T-\mu
\end{array}\right)\left(\begin{array}{cc}
T_{1}^{-1} & 0 \\
0 & 1
\end{array}\right)\left(\begin{array}{c}
\widehat{f} \\
\widehat{v}
\end{array}\right)= \\
& =\left(\begin{array}{cc}
\frac{1}{r} T-\mu & 2 \lambda R v \\
-2 \lambda R A T_{1}^{-1} & \frac{1}{r} T-\mu
\end{array}\right)\left(\begin{array}{c}
\widehat{f} \\
\widehat{v}
\end{array}\right)= \\
& =\left[\left(\begin{array}{cc}
\frac{1}{r} T & 0 \\
0 & \frac{1}{r} T
\end{array}\right)+2 \lambda R\left(\begin{array}{cc}
0 & v \\
-A T_{1}^{-1} & 0
\end{array}\right)-\mu\left(\begin{array}{ll}
1 & 0 \\
0 & 1
\end{array}\right)\right]\left(\begin{array}{l}
\widehat{f} \\
\widehat{v}
\end{array}\right)= \\
& =\left(\frac{1}{r} \mathbf{T}+\mathbf{P}-\mu \mathbf{E}\right) \mathbf{F} .
\end{aligned}
$$

Here

$$
\mathbf{T}=\left(\begin{array}{ll}
T & 0 \\
0 & T
\end{array}\right), \mathbf{P}=\left(\begin{array}{ll}
0 & 2 \lambda R v \\
-2 \lambda R A T_{1}^{-1} & 0
\end{array}\right)
$$




$$
\mathbf{Q}=\left(\begin{array}{ll}
T_{1}^{-1} & 0 \\
0 & 1
\end{array}\right), \mathbf{E}=\left(\begin{array}{ll}
1 & 0 \\
0 & 1
\end{array}\right)
$$

From (6), we obtain

$$
\left(\frac{1}{r} \mathbf{T}+\mathbf{P}\right) \mathbf{F}=\mu \mathbf{F}, \mathbf{F} \in \mathbf{D}_{\mathbf{T}}
$$

where

$$
\mathbf{D}_{\mathbf{T}}=\left(\begin{array}{c}
\mathbf{F}=\left(\begin{array}{c}
\widehat{f} \\
\widehat{v}
\end{array}\right), \mathbf{U}=\left(\begin{array}{c}
\widehat{\psi} \\
\widehat{v}
\end{array}\right), \\
\left\{\widehat{f} \mid \widehat{f} \in C^{2}\left(r_{1}, r_{2}\right) \cap C^{1}\left[r_{1}, r_{2}\right], \frac{1}{r} T \widehat{f} \in L_{2}^{r}\left[r_{1}, r_{2}\right],\right. \\
\left.\left.\frac{d \widehat{f}(r)}{d r}\right|_{r=r_{1}, r_{2}}=0\right\} \\
\left\{\widehat{v} \mid \widehat{v} \in C^{2}\left(r_{1}, r_{2}\right) \bigcap C^{1}\left[r_{1}, r_{2}\right], \frac{1}{r} T \widehat{v} \in L_{2}^{r}\left[r_{1}, r_{2}\right],\right. \\
\left.\left.\widehat{v}(r)\right|_{r=r_{1}, r_{2}}=0\right\}
\end{array}\right) .
$$

The sets of eigenvalues of the spectral problems (6) and (8) coincide, and their eigenfunctions $\mathbf{F}$ and $\mathbf{U}$ are related by the equality

$$
\mathrm{U}=\mathrm{QF} \text {. }
$$

Theorem 2. Spectral problem

$$
\frac{1}{r} \mathbf{T F}_{0}=\beta \mathbf{F}_{0}, \mathbf{F}_{0} \in \mathbf{D}_{\mathbf{T}}, \mathbf{F}_{0}=\left(\begin{array}{c}
\widehat{f}_{0} \\
\widehat{v}_{0}
\end{array}\right)
$$

has set of eigenvalues $\left\{\beta_{n}\right\}_{n=1}^{\infty}$ :

$$
\begin{gathered}
\beta_{n} \in A_{g} \bigcup A_{q}, \\
A_{g}=\left\{\lambda^{2}+g_{n}^{2}\right\}_{n=1}^{\infty}, A_{q}=\left\{\lambda^{2}+q_{n}^{2}\right\}_{n=1}^{\infty}
\end{gathered}
$$

and many eigenfunctions:

$$
\mathbf{F}_{0_{n}}=\left\{\left(\begin{array}{l}
\chi_{A_{g}}\left(\beta_{n}\right) \widehat{f}_{0_{n}}(r) \\
\chi_{A_{q}}\left(\beta_{n}\right) \widehat{v}_{0_{n}}(r)
\end{array}\right)\right\}_{n=1}^{\infty}, r_{1} \leq r \leq r_{2} .
$$

Here

$$
\begin{gathered}
\widehat{f}_{0_{n}}(r)=C_{2 n}\left[S_{1}\left(g_{n}\right) Y_{1}\left(g_{n} r\right)-S_{2}\left(g_{n}\right) J_{1}\left(g_{n} r\right)\right], \\
S_{1}(g)=-\frac{1}{\lambda^{2}+g^{2}}\left[\lambda r_{2} G_{2}\left(\beta r_{2}, \lambda r_{2}\right) J_{1}\left(g r_{2}\right)-g r_{1} G_{1}\left(\lambda r_{2}, \lambda r_{1}\right) J_{0}\left(g r_{1}\right)-\beta r_{1} G_{2}\left(\lambda r_{1}, \lambda r_{2}\right) J_{1}\left(g r_{1}\right)\right], \\
S_{2}(g)=-\frac{1}{2+g^{2}}\left[\lambda r_{2} G_{2}\left(\lambda r_{2}, \lambda r_{2}\right) Y_{1}\left(g r_{2}\right)-g r_{1} G_{1}\left(\lambda r_{2}, \lambda r_{1}\right) Y_{0}\left(g r_{1}\right)-\lambda r_{1} G_{2}\left(\lambda r_{1}, \beta r_{2}\right) Y_{1}\left(g r_{1}\right)\right], \\
g_{n}-\text { roots of the equation: } \\
\quad\left[r_{2} G_{1}\left(\lambda r_{2}, \lambda r_{1}\right) g Y_{0}\left(g r_{2}\right)-r_{2} \lambda G_{2}\left(\lambda r_{2}, \lambda r_{1}\right) Y_{1}\left(g r_{2}\right)+r_{1} \lambda G_{2}\left(\lambda r_{1}, \lambda r_{1}\right) Y_{1}\left(g r_{1}\right)\right] \times \\
\times\left[r_{2} \lambda G_{2}\left(\lambda r_{2}, \lambda r_{2}\right) J_{1}\left(g r_{2}\right)-r_{1} G_{1}\left(\lambda r_{2}, \lambda r_{1}\right) g J_{0}\left(g r_{1}\right)-r_{1} \lambda G_{2}\left(\lambda r_{1}, \lambda r_{2}\right) J_{1}\left(g r_{1}\right)\right]- \\
\quad-\left[r_{2} \lambda G_{2}\left(\lambda r_{2}, \lambda r_{2}\right) Y_{1}\left(g r_{2}\right)-r_{1} G_{1}\left(\lambda r_{2}, r_{1}\right) g Y_{0}\left(g r_{1}\right)-r_{1} \lambda G_{2}\left(r_{1}, \lambda r_{2}\right) Y_{1}\left(g r_{1}\right)\right] \times \\
\times\left[r_{2} G_{1}\left(\lambda r_{2}, \lambda r_{1}\right) g J_{0}\left(g r_{2}\right)-r_{2} \lambda G_{2}\left(\lambda r_{2}, \lambda r_{1}\right) J_{1}\left(g r_{2}\right)+r_{1} \lambda G_{2}\left(\lambda r_{1}, \lambda r_{1}\right) J_{1}\left(g r_{1}\right)\right]=0,
\end{gathered}
$$


$\widehat{v}_{0_{n}}(r)=C_{4 n}\left[J_{1}\left(q_{n} r_{1}\right) Y_{1}\left(q_{n} r\right)-Y_{1}\left(q_{n} r_{1}\right) J_{1}\left(q_{n} r\right)\right], q_{n}$ - roots of the equation:

$$
J_{1}\left(q r_{1}\right) Y_{1}\left(q r_{2}\right)-J_{1}\left(q r_{2}\right) Y_{1}\left(q r_{1}\right)=0,
$$

$\chi_{A_{\eta}} u \chi_{A_{\zeta}}-$ characteristic functions of sets $A_{\eta}$ and $A_{\zeta}$ respectively, $G_{1}(\xi, \eta)=I_{1}(\xi) K_{1}(\eta)-$ $I_{1}(\eta) K_{1}(\xi), G_{2}(\xi, \eta)=I_{1}(\xi) K_{1}(\eta)+I_{1}(\eta) K_{1}(\xi)$.

Theorem 3. A set of eigenvalues $\left\{\beta_{n}\right\}_{n=1}^{\infty}$ of the problem (9) has no finite limit points, and all eigenvalues are real, non-negative and simple.

Theorem 4. Eigenfunctions (10) of the spectral problem (9) corresponding to different eigenvalues are orthogonal in $L_{2}^{r}\left[r_{1}, r_{2}\right]$.

Theorem 5. An operator $\mathbf{P}$ is restricted in $L_{2}^{r}\left[r_{1}, r_{2}\right]$ and

$$
\|\mathbf{P}\| \leq 2 \lambda R \max _{r_{1} \leq r \leq r_{2}}\left(|v|, \frac{|A|}{\lambda^{2}}\right)
$$

Theorem 6. An operator $\frac{\mathbf{1}}{\mathbf{r}} \mathbf{T}$ with the domain of definition $\mathbf{D}_{\mathbf{T}}$ is a discrete semi-bounded from below in $L_{2}^{r}\left[r_{1}, r_{2}\right]$.

Scalar product $\left(\mathbf{P F}_{0_{n}}, \mathbf{F}_{0_{m}}\right)_{r}$ for any $n, m \in N$ is computed by the formulas:

$$
\begin{gathered}
V_{n m}=\left(\mathbf{P F}_{0_{n}}, \mathbf{F}_{0_{m}}\right)_{r}=\int_{r_{1}}^{r_{2}} r\left[\mathbf{P F}_{0_{n}}\right]^{T} \mathbf{F}_{0_{m}} d r= \\
=2 \lambda R\left[\chi_{A_{g}}\left(\beta_{n}\right) \chi_{A_{q}}\left(\beta_{m}\right) \int_{r_{1}}^{r_{2}} r v(r) \widehat{v}_{0_{n}}(r) \widehat{f}_{0_{m}}(r) d r-\right. \\
\left.-\chi_{A_{q}}\left(\beta_{n}\right) \chi_{A_{g}}\left(\beta_{m}\right) \int_{r_{1}}^{r_{2}} r v(r) \widehat{v}_{0_{m}}(r) T_{1}^{-1}\left(\widehat{f}_{0_{n}}(r)\right) d r\right] .
\end{gathered}
$$

To compute the eigenvalues of the spectral problem (8) and, therefore, the Couette problem (4), (5) by the method of regularized traces, we propose the following algorithm:

1. Using theorem 1 , to find the eigenvalues $\left\{\beta_{k}\right\}_{k=1}^{k_{0}}$ of spectrum problem (9). To enumerate founded eigenvalues of $\beta_{k}$ in descending order of value.

2. To find the orthogonal system of eigenfunctions $\left\{\mathbf{F}_{0}\right\}_{k=1}^{k_{0}}$ of the boundary problem (9) and to normalize it.

3. To find $n_{0}$ from inequalities

$$
\frac{2|| \mathbf{P} \|}{\left|\beta_{n+1}+\beta_{n}\right|}<1
$$

such that they are true for all $n \leq n_{0} \leq k_{0}$.

4. To calculate the scalar product of $V_{n n}$ by the formulas (11) for all $n \leq n_{0}$.

5 . To calculate approximate eigenvalues $\left\{\widetilde{\mu}_{n}\right\}_{n=1}^{n_{0}}$ of the boundary problem (9) using equations (2) for all $n \leq n_{0}$. 

$(5)$.

6. Using $\mu=R \sigma$, to find approximate eigenvalues $\left\{\widetilde{\sigma}_{n}\right\}_{n=1}^{n_{0}}$ of the spectral problem (4),

The results of the calculation of the first eigenvalues $\widetilde{\sigma}_{n}$ of the Couette problem (4), (5), which are obtained by the method of RS, were compared with calculation of them by the method of Galerkin. In all cases, the results coincide with good veracity.

Table shows the first four eigenvalues of the Couette problem for the case $\lambda=10$, $\frac{R_{2}}{R_{1}}=3, \frac{\Omega_{2}}{\Omega_{1}}=0,5$.

\section{Table}

The results of the calculation of approximate eigenvalues $\widetilde{\sigma}_{j}$ of the spectral problem (4), (5) by method of RS

\begin{tabular}{|c|c|c|}
\hline$j$ & $\widetilde{\sigma}_{j}$ & $\widetilde{\sigma}_{j}$ \\
\hline & $R=10000$ & $R=100000$ \\
\hline 1 & $-0,010707-1,446012 i$ & $-0,001071-1,446017 i$ \\
\hline 2 & $-0,010707+1,446012 i$ & $-0,010707+1,446017 i$ \\
\hline 3 & $-0,011396-1,344948 i$ & $-0,001139-1,344955 i$ \\
\hline 4 & $-0,011396+1,344948 i$ & $-0,001139+1,344955 i$ \\
\hline
\end{tabular}

Numerical experiments have shown the high computational efficiency of the constructed algorithm for computing of the eigenvalues of the studied spectral problem.

\section{Conclusion}

The application of the method of regularized traces for computing of the eigenvalues of the spectral problem and the Couette problem is developed. To this end the auxiliary boundary problem (9) is constructed. This problem is generated by the matrix perturbed self-adjoint operator, such that its eigenvalues set coincides with the same set of Couette problem. Theorems that allow to justify the legitimacy of application of the RT method for finding of the eigenvalues of the constructed problem are obtained. The algorithm of application of method for the RT spectral problems generated by the discrete matrix operators limited from below is constructed.

\section{References}

1. Sadovnichii V.A., Dubrovskii V.V., Kadchenko S.I., Kravchenko V.F. Evaluation of the First Eigenvalues of the Boundary-Value Hydrodynamic Stability Problem for a Flow between Two Parallel Planes at Small Reynolds Numbers. Doklady Akademii Nauk, 1997, vol. 335, no. 5, pp. 600-604. (in Russian)

2. Dubrovskii V.V., Kadchenko S.I., Kravchenko V.F., Sadovnichii V.A. [Calculation of the First Eigenvalues of the Boundary Value Problem Orr - Sommerfeld Using the Theory of Regularized Traces]. Elektromagnitnye volny i elektronnye systemy [Electromagnetic Waves and Electronic Systems], 1997, vol. 2, no. 6, pp. 13-19. (in Russian)

3. Dubrovskii V.V., Kadchenko S.I., Kravchenko V.F., Sadovnichy V.A. Computation of the First Eigenvalues of a Discrete Operator. Elektromagnitnye volny $i$ elektronnye systemy [Electromagnetic Waves and Electronic Systems], 1998, vol. 3, no. 2, pp. 6-8. (in Russian) 
4. Sadovnichii V.A., Dubrovskii V.V., Kadchenko S.I., Kravchenko V.F. Computation of Lower Eigenvalues of the Boundary Value Problem on the Hydrodynamic Stability of Poiseuille Flow in a Round Tube. Differentsial'nye uravneniya [Differential Equations], 1998, vol. 34, no. 1, pp. 50-53. (in Russian)

5. Kadchenko S.I. A New Method for Calculating Eigenvalues of the Spectral Problem Orr - Sommerfeld. Elektromagnitnye volny $i$ elektronnye systemy [Electromagnetic Waves and Electronic Systems], 2000, vol. 5, no. 6, pp. 4-10. (in Russian)

6. Dubrovskii V.V., Kadchenko S.I., Kravchenko V.F. A New Method for Approximate Evaluation of the First Eigenvalues in the Spectral Problem of Hydrodynamic Stability of Poiseuille Flow in a Circular Pipe. Doklady Mathematics, 2001, vol. 64, no. 2, pp. $165-168$.

7. Kadchenko S.I. A New Method for Computing the First Eigenvalues of Non-Selfadjoint Discrete-Time Operators. Sobolev Type Equations, 2002, pp. 42-59. (in Russian)

8. Kadchenko S.I. [A New Method of Calculation of Adjustment Series of the Perturbation Theory for Discrete Operators]. Bulletin of Chelyabinsk State University, 2003, vol. 3, no. 3, pp. 67-85. (in Russian)

9. Kadchenko S.I. Calculation of the Sums of the Series of the Rayleigh - Schrodinger Discrete-Time Operators. Vestnik MaGU. Estestvennye nauki, 2004, issue 5, pp. 137143. (in Russian)

10. Kadchenko S.I., Kinzina I.I. Linear Equations for Approximate Calculation of Eigenvalues of Perturbed Self-Adjoint Operators. Elektromagnitnye volny $i$ elektronnye systemy [Electromagnetic Waves and Electronic Systems], 2005, vol. 10, no. 6, pp. 4-12. (in Russian)

11. Kadchenko S.I., Kinzina I.I. Computation of Discrete Eigenvalues of Non-Selfadjoint Linear Operators on Formulas. Vestnik MaGU. Matematika, 2005, issue 8, pp. 87-95. (in Russian)

12. Kadchenko S.I., Kinzina I.I. Computation of Eigenvalues of Perturbed Discrete Semibounded Operators. Computational Mathematics and Mathematical Physics, 2006, vol. 46, no. 7, pp. 1200-1206. DOI: 10.1134/S0965542506070116

13. Kadchenko S.I. Computing the Sums of Rayleigh - Schrodinger Series of Perturbed Self-Adjoint Operators. Computational Mathematics and Mathematical Physics, 2007, vol. 47, no. 9. pp. 1446-1451. DOI: 10.1134/S0965542506070116

14. Kadchenko S.I. The Method of Regularized Traces. Bulletin of the South Ural State University. Series: Mathematical Modelling, Programming and Computer Software, 2009, no. 37 (170), issue 4, pp. 4-23. (in Russian)

15. Kadchenko S.I., Ryazanov S.L. A Numerical Method of Finding Eigenvalues of the Discrete Semi-Bounded from Below Operators. Bulletin of the South Ural State University. Series: Mathematical Modelling, Programming and Computer Software, 2011, no. 17 (234), issue 8, pp. 46-51. (in Russian)

16. Lin, C.C. The Theory of Hydrodynamic Stability. Moscow, Inost. lit., 1987. 195 p. (in Russian) 
Sergey I. Kadchenko, doctor of physical and mathematical sciences, professor, department of Applied Mathematics and Computer Science, Nosov Magnitogorsk State Technical University, Magnitogorsk, Russian Federation, kadchenko@masu.ru.

Lyubov S. Ryazanova, candidate of physical and mathematical sciences, professor, department of Applied Mathematics and Computer Science, Nosov Magnitogorsk State Technical University, Magnitogorsk, Russian Federation, kadchenko@masu.ru.

Angelina I. Kadchenko, candidate of technical sciences, associate professor, department of Mathematics 1, Nosov Magnitogorsk State Technical University, Magnitogorsk, Russian Federation, kadchenko@masu.ru.

Received October 7, 2015

УДК 519.642.8

DOI: $10.14529 /$ jcem 150404

\section{ВЫЧИСЛЕНИЕ СОБСТВЕННЫХ ЗНАЧЕНИЙ СПЕКТРАЛЬНОЙ ЗАДАЧИ КУЭТТА МЕТОДОМ РЕГУЛЯРИЗОВАННЫХ СЛЕДОВ}

\section{С.И. Кадченко, Л.С. Рязанова, А.И. Кадченко}

Собственные числа несамосопряженных операторов можно найти только численными методами, применение которых связано с большими вычислительными трудностями. Поэтому разработка нового метода вычисления собственных значений несамосопряженных операторов представляет большой теоретический и практический интерес. На основе теории регуляризованных следов разработан неитерационный метод нахождения собственньх значений возмущенных самосопряженных операторов, который был назван методом регуляризованных следов. Найдены линейные формулы для вычисления собственных значений дискретных полуограниченных снизу операторов. Используя их, можно вычислять собственные значения возмущенного самосопряженного оператора с любым их номером, независимо от того, известны ли собственные значения с предыдущими номерами или нет. Численные расчеты собственных значений для спектральных задач, порожденные уравнениями математической физики, показывают, что предлагаемые формулы при больших номерах собственных значений дают результат точнее, чем метод Галеркина. Кроме того, по найденным формулам можно вычислять собственные значения возмущенного самосопряженного оператора с очень большими номерами, когда применение метода Галеркина становится затруднительным. Разработан алгоритм применения метода регуляризованных следов для нахождения собственных значений спектральной задачи Куэтта гидродинамической теории устойчивости, которая исследует устойчивость течения вязкой жидкости между двумя вращающимися осесимметричными цилиндрами к малым возмущениям основного течения. Особеностью задачи является тот факт, что дифференциальный оператор является матричным. Проведенные численные эксперименты показали высокую вычислительную эффективность разработанного алгоритма вычисления собственных значений исследуемой спектральной задачи.

В работе построен алгоритм применения метода регуляризованных следов к спектральным задачам, порожденным матричными дискретными ограниченными снизу операторами.

Ключевые слова: собственные значения и собственные функции операторов; поправки теории возмущений; дискретные операторы; самосопряженные операторы; гидродинамическая теории устойчивости. 


\section{Литература}

1. Садовничий, В.А. Вычисление первых собственных чисел краевой задачи гидродинамической устойчивости течения между параллельными плоскостями при малых числах Рейнольдса / В.А. Садовничий, В.В. Дубровский, С.И. Кадченко, В.Ф. Кравченко // Доклады Академии наук. - 1997. - Т. 335, № 5. - С. 600-604.

2. Дубровский, В.В. Вычисление первых собственных чисел краевой задачи Орра Зоммерфельда с помощью теории регуляризованных следов / В.В. Дубровский, С.И. Кадченко, В.Ф. Кравченко, В.А. Садовничий // Электромагнитные волны и электронные системы. - 1997. - Т. 2, № 6. - С. 13-19.

3. Дубровский, В.В. Вычисление первых собственных чисел дискретного оператора / В.В. Дубровский, С.И. Кадченко, В.Ф. Кравченко, В.А. Садовничий // Электромагнитные волны и электронные системы. - 1998. - Т. 3, № 2. - С. 6-8.

4. Садовничий, В.А. Вычисление первых собственных чисел краевой задачи гидродинамической устойчивости течения Пуазейля в круглой трубе / В.А. Садовничий, В.В. Дубровский, С.И. Кадченко, В.Ф. Кравченко // Дифференциальные уравнения. - 1998. - Т. 34, № 1. - С. 50-53.

5. Кадченко, С.И. Новый метод вычисления собственных чисел спектральной задачи Орра - Зоммерфельда / С.И. Кадченко // Электромагнитные волны и электронные системы. - 2000. - Т. 5, № 6. - С. 4-10.

6. Дубровский, В.В. Новый метод приближенного вычисления первых собственных чисел спектральной задачи гидродинамической устойчивости течения Пуазейля в круглой трубе / В.В. Дубровский, С.И. Кадченко, В.Ф. Кравченко, В.А. Садовничий // Доклады Академии наук. - 2001. - Т. 381, № 3. - С. 320-324.

7. Кадченко, С.И. Новый метод вычисления первых собственных чисел дискретных несамосопряженных операторов / С.И. Кадченко // Уравнения соболевского типа. - Челябинск, 2002. - С. 42-59.

8. Кадченко, С.И. Новый метод вычисления рядов поправок теории возмущений дискретных операторов / С.И. Кадченко // Вестник ЧелГУ. - 2003. - Т. 3, № 3. C. $67-85$.

9. Кадченко, С.И. Вычисление сумм рядов Релея - Шредингера дискретных операторов / С.И. Кадченко // Вестник МаГУ. Естественные науки. - Вып. 5. Магнитогорск, 2004. - С. 137-143.

10. Кадченко, С.И. Линейные уравнения для приближенного вычисления собственных чисел возмущенных самосопряженных операторов / С.И. Кадченко, И.И. Кинзина // Электромагнитные волны и электронные системы. - 2005. T. 10 , № $6 .-$ C. $4-12$.

11. Кадченко, С.И. Вычисление собственных чисел дискретных несамосопряженных операторов по линейным формулам / С.И. Кадченко, И.И. Кинзина // Вестник МаГУ. Математика. - Вып. 8. - Магнитогорск, 2005. - С. 87-95.

12. Кадченко, С.И. Вычисление собственных значений возмущенных дискретных полуограниченных операторов / С.И. Кадченко, И.И. Кинзина // Журнал вычислительной математики и математической физики. - 2006. - Т. 46, № 7 . C. $1265-1272$. 
13. Кадченко, С.И. Вычисление сумм рядов Релея - Шредингера возмущенных самосопряженных операторов / С.И. Кадченко // Журнал вычислительной математики и математической физики. - 2007. - Т. 47, № 9. - С. 1494-1505.

14. Кадченко, С.И. Метод регуляризованных следов / С.И. Кадченко // Вестник ЮУрГУ. Серия: Математическое моделирование и программирование. - 2009. № 37 (170), вып. 4. - С. 4-23.

15. Кадченко, С.И. Численный метод нахождения собственных значений дискретных полуограниченных снизу операторов / С.И. Кадченко, Л.С. Рязанова // Вестник ЮУрГУ. Серия: Математическое моделирование и программирование. - 2011. № 17 (234), вып. 8. - С. 46-51.

16. Линь, Ц.Ц. Теория гидродинамической устойчивости / Ц.Ц. Линь. - М.: Иностр. лит., 1987. - 195 с.

Кадченко Сергей Иванович, доктор физико-математических наук, профессор, кафедра прикладной математики и информатики, Магнитогорский государственный технический университет им. Г.И. Носова (г. Магнитогорск, Российская Федераuия),kadchenko@masu.ru.

Рязанова Любовь Сергеевна, кандидат педагогичесикх наук, дочент, кафедра прикладной математики и информатики, Магнитогорский государственный технический университет им. Г.И. Носова (г. Магнитогорск, Российская Федерация), ryazanova2006@rambler.ru.

Кадченко Ангелина Ивановна, кандидат технических наук, дочент, кафедра высшей математики 1, Магнитогорский государственный технический университет им. Г.И. Носова (г. Магнитогорск, Российская Федерация), akadchenko@mail.ru.

Поступила в редакиию 7 октября 2015. 